\title{
Biodegradable materials for surgical management of infective endocarditis: new solution or a dead end street?
}

\author{
Patrick O Myers ${ }^{*}$, Mustafa Cikirikcioglu and Afksendiyos Kalangos
}

\begin{abstract}
Background: One third of patients with infective endocarditis will require operative intervention. Given the superiority of valve repair over valve replacement in many indications other than endocarditis, there has been increasing interest and an increasing number of reports of excellent results of valve repair in acute infective endocarditis. The theoretically ideal material for valve repair in this setting is non-permanent, "vanishing" material, not at risk of seeding or colonization. The goal of this contribution is to review currently available data on biodegradable materials for valve repair in infective endocarditis.

Discussion: Rigorous electronic and manual literature searches were conducted to identify reports of biodegradable materials for valve repair in infective endocarditis. Articles were identified in electronic database searches of Medline, Embase and the Cochrane Library, using a predetermined search strategy. 49 manuscripts were included in the review. Prosthetic materials needed for valve repair can be summarized into annuloplasty rings to remodel the mitral or tricuspid annulus, and patch materials to replace resected valvar tissue. The commercially available biodegradable annuloplasty ring has shown interesting clinical results in a single-center experience; however further data is required for validation and longer follow-up. Unmodified extra-cellular matrix patches, such as small intestinal submucosa, have had promising initial experimental and clinical results in non-infected valve repair, although in valve repair for endocarditis has been reported in only one patient, and concerns have been raised regarding their mechanical stability in an infected field.

Summary: These evolving biodegradable devices offer the potential for valve repair with degradable materials replaced with autologous tissue, which could further improve the results of valve repair for infective endocarditis. This is an evolving field with promising experimental or initial clinical results, however long-term outcomes are lacking and further data is necessary to validate this theoretically interesting approach to infective endocarditis.
\end{abstract}

Keywords: Endocarditis, Valve repair, Biodegradable materials

\section{Background}

Infective endocarditis is a serious disease with an incidence of 30 to 100 per million patient-years [1-3]. Mortality is high: more than a third of patients will die within the first year of diagnosis $[4,5]$. The role of surgery in the treatment of infective endocarditis has been expanding, and current guidelines advocate surgical management for complicated infective endocarditis [6,7]; approximately one third of patients with infective endocarditis will

\footnotetext{
* Correspondence: patrick.myers@hcuge.ch

Cardiovascular Surgery, Geneva University Hospitals \& Faculty of Medicine, 4 rue Gabrielle-Perret-Gentil, 1211 Geneva, Switzerland
}

require operative intervention [8]. Early surgery is strongly indicated for patients with infective endocarditis and congestive heart failure, large left-sided vegetations $(>10 \mathrm{~mm})$ at high risk of embolism, persistent or locally uncontrolled infection (abscess, false aneurysm, fistula or enlarging vegetation), varying between a recommendation of class I to IIa and a level of evidence of B to C [5].

Operative principles for infective endocarditis include complete debridement of infected tissues, drainage of abscess cavities followed by restoration of anatomic relationships, such as ventriculo-aortic or atrioventricular continuity [9]. Several surgical options exist to restore a competent valve depending on the extent of valve 
destruction by the infectious process, ranging from valve repair to valve replacement. Valve replacement with an off-the shelf prosthetic valve in the setting of active infection can lead to recurrent infection, estimated between $2 \%$ to $9 \%[9,10]$. Infection-resistant prosthetic valves have been developed, however their results are poor and no devices are currently approved for clinical use. The multicenter prospective randomized Artificial Valve Endocarditis Reduction Trial (AVERT), using a prosthetic valve made with a silver Silzone-coated sewing cuff, was stopped before completion due to a higher rate of major paravalvular leaks requiring reoperation [11]. Other modalities, such as biodegradable matrices that secrete antibacterial proteins [12], are still at the stage of basic research and have yet to be tested in clinical settings. Homografts have been advanced as an ideal substitute in the setting of active endocarditis due to their biological nature and absence of foreign woven material, although they remain susceptible to recurrent infection [13] and complicate the initial and subsequent valve replacements.

Given the superiority of valve repair over valve replacement in many indications $[14,15]$ other than endocarditis, there has been increasing interest and an increasing number of reports of excellent results of valve repair in acute infective endocarditis [16].

\section{Discussion}

\section{Rationale for Biodegradable Materials in Infective Endocarditis}

Monofilament suture has been shown to be less susceptible to colonization in in vitro and in vivo laboratory studies compared to braided multifilament suture [17-20]. However, in the setting of an infected surgical field which requires placement of foreign material to perform the planned operation, the theoretically ideal material is nonpermanent, "vanishing" material [21], dissolving and to be replaced by autologous tissue. The prosthetic materials needed for valve repair can be summarized into annuloplasty rings to remodel the mitral or tricuspid annulus, and patch materials to replace resected valvar tissue.

With the use of adapted perioperative antibiotics and complete surgical debridement, the rate of recurrent endocarditis is, as mentioned previously, quite low both in valve repair and replacement. This implies that any study looking at these technologies, beyond the "proof of concept" phase, will need a large number of patients and rigorous follow-up to have sufficient power to see if these new biodegradable materials can do better than conventional techniques.

\section{Biodegradable Annuloplasty}

It is tempting to avoid an annuloplasty ring when fixing limited leaflet destruction from mitral or tricuspid valve infective endocarditis [22], under the assumption that the underlying mechanism is acute regurgitation and usually doesn't involve annular dilatation. Annuloplasty plays an important role in valve reconstruction, particularly if a significant infected leaflet segment must be resected, to relieve tension on the repaired leaflets and ensure long-term stability of the repair. Traditional annuloplasty rings and bands, predominantly made of polyester mesh, are susceptible to seeding and infection. Ciprofloxacin-coated polyester annuloplasty ring mesh was shown to confer infection resistance in a subcutaneous animal implantation model [23], however these devices haven't been reported in clinical use to date.

Temporary annuloplasty with a biodegradable device replaced with autologous fibrous tissue would theoretically reduce the risk of infection recurrence and durably remodel the annulus. Duran et al. reported the results of DeVega annuloplasty using 2-0 polydioxanone suture in an experimental sheep model [24], as well as their clinical results in 73 patients with functional tricuspid regurgitation [25], showing that this provided temporary "vanishing" annuloplasty that stabilizes the annulus for 4 months. There has been no further follow-up data from this patient cohort, and no similar reports beyond functional tricuspid regurgitation.

The Bioring Kalangos annuloplasty ring (formerly Bioring SA, Lonay, Switzerland) was developed to extend the annular stabilization beyond this time period, while remaining biodegradable. It is a curved "C" segment of poly-1,4-dioxanone polymer located on a non-degradable polyvinyl monofilament suture equipped with a stainless steel needle at each extremity. This ring is inserted subendocardially directly into the mitral or tricuspid annulus, away from blood contact. In a juvenile pig model [26], it was shown to dissolve in 6 months and be replaced at 12 months by autologous fibrous tissue (see Figure 1). The close proximity of important structures to the posterior mitral annulus, such as the circumflex coronary artery and the great cardiac vein, has raised questions regarding the safety of implanting the ring into the native annulus. This issue was addressed by Cikirikcioglu et al. in a

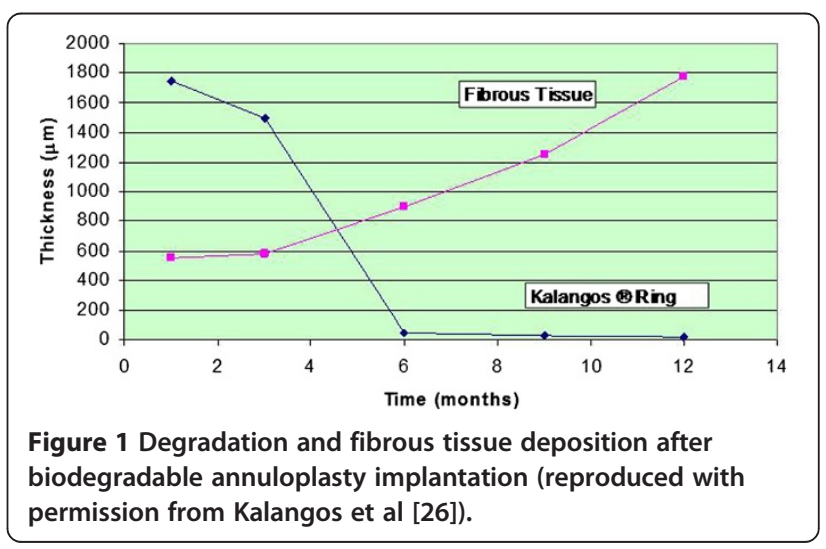


cadaveric study, which showed that the distances between the ring and the circumflex coronary artery was $7.2 \pm$ $2.7 \mathrm{~mm}, 11.0 \pm 2.4 \mathrm{~mm}$, and $10.7 \pm 3.8 \mathrm{~mm}$ at the level of anterolateral commissure, the mid posterior annulus, and the posteromedial commissure, respectively [27].

Clinical results have been reported in children with rheumatic mitral regurgitation [28], congenital mitral $[29,30]$ and tricuspid [31] regurgitation. The results have been positive so far, with evidence of durable stabilization of the mitral or tricuspid annulus while allowing for growth in this pediatric patient population, as evidenced by stable annular diameter Z-scores. Panos et al. also reported the ease of implantation of this ring in minimally invasive thoracoscopic or robotic mitral and tricuspid valve repair [32]. Finally, Pektok et al. reported the histological findings 21 months after implantation in an adult patient with ischemic mitral regurgitation, confirming that the ring is degraded and replaced by dense autologous fibrous tissue along the posterior mitral annulus [33].

The infection resistance of the biodegradable annuloplasty ring was tested in an in vivo rat animal model study, compared to the Carpentier-Edwards (Edwards Lifesciences Corp, Irvine, CA, USA) Physio II ring (M. Cikirikcioglu, personal communication, presented at AATS mitral conclave 2013, poster E57: "infection resistance testing of biodegradable annuloplasty ring in a rat subcutaneous implantation model"). In this study, segments of annuloplasty ring were implanted subcutaneously and topically inoculated with $2 \times 10^{7}$ colony forming units (CFU) of Staphylococcus aureus. Cultures of explanted rings were more frequently positive in conventional rings $(11 / 16)$ than the biodegradable ring $(2 / 16, P=0.003)$, and the amount of growing bacteria was also significantly increased in conventional rings $(7175 \pm 5936 \mathrm{CFU} / \mathrm{ml}$ vs. $181 \pm 130 \mathrm{CFU} / \mathrm{ml}$ in the biodegradable ring, $P=0.0005)$.

Clinical use of the biodegradable ring has been reported for valve repair in infective endocarditis by Kazaz et al. [34] and by our group [35,36]. From 2004 to 2009, we implanted the ring in 17 patients with acute infective endocarditis, 13 in the mitral, 3 in the tricuspid and 1 in both valves [35]. There were 3 early deaths, and no late evidence of endocarditis recurrence, valve dysfunction, reoperations or deaths at a mean follow-up of 30 months. We updated this report with our experience in 8 children with infective endocarditis [36]. There were no early or late deaths, reoperations or evidence of endocarditis recurrence at a mean follow-up of 56 months.

These different studies are limited for the most part by the fact that most data originated from our group (and are currently being validated by more widespread use of these devices) and a follow-up that extends to a maximum of 9 years now. This data represents little more than a "proof of concept", providing data on our initial favorable experience, and mandates larger multi-center prospective randomized studies to validate these initial findings made in selected patients in a the hands of dedicated team.

\section{Biodegradable Patches}

Surgical management of infective endocarditis entails debridement of all infected tissue, which may include leaflets, the annulus or structures beyond the annulus (such as the atrioventricular groove or the ventriculoarterial continuity), which require reconstruction. There is relatively little data on leaflet patch reconstruction in infective endocarditis, beyond a few limited case reports or series. More generally in leaflet repair, all available patch materials have disappointing mid- and long-term results. Autologous fresh pericardium retracts with time, while glutaraldehyde-fixed pericardium calcifies [37]. Expanded polytetrafluoroethylene has been proposed as a leaflet repair patch material [38], however mid- and long-term follow-up data is still pending and this material may be at risk of calcification [39] or late fracture [40]. Each of these materials are permanent, nondegradable and at risk of seeding and the cause of recurrent infection.

Given the poor long-term results of leaflet patch augmentation overall (and not just in the setting of infective endocarditis), new patch materials are being developed to realize the dream of in vivo valvulogenesis, using scaffolds intended to be colonized and replaced by autologous tissue. Several synthetic scaffolds have been proposed in vitro and in animal models, such as polydiaxonone [41], polyglycolic acid, poly-L-lactic acid [42] or polyurethane. Their clinical application as a biodegradable patch for valve repair remains to be reported.

Biological scaffolds have also been developed, predominantly using extracellular matrix (ECM). The structural and functional components of ECM are transient, due to the rapid rate of degradation of ECM scaffolds in vivo [43]; they could be considered as temporary controlled release vehicles for naturally occurring growth factors. The characteristic of the intact ECM that distinguishes it from other scaffold materials is its diversity of structural proteins and associated bioactive molecules and their unique spatial distribution. ECM can be harvested for use as a therapeutic scaffold from the dermis, submucosa of the small intestine and urinary bladder, pericardium, basement membrane and stroma of the decellularized liver, and the decellularized Achilles tendon [43] (see Figure 2). Although there is abundant literature on modified ECM as a scaffold (e.g. in biological prosthetic heart valves or glutaraldehyde-treated pericardium), the data is newer on ECM that hasn't been modified, except for decellularlization and sterilization. As reviewed in detail by Badylak [43], ECM scaffolds that 
remain essentially unchanged from native ECM elicit a host response that promotes cell infiltration and rapid scaffold degradation, deposition of host derived neomatrix and constructive tissue remodeling with minimal scar tissue; this represents a fundamentally different scaffold material than ECM that has been chemically or otherwise modified.

CorMatrix $\odot$ is a commercially available ECM scaffold made of non-modified small intestinal submucosa. Initially approved for pericardial replacement, its use has been expanded as a patch for intracardiac [44] and vascular reconstruction [45]. Its application in heart valve repair is relatively new, and there is a paucity of data available. In a retrospective study of 25 children with congenital mitral or tricuspid lesions who underwent leaflet patch augmentation with CorMatrix $\odot$, the reoperation rate was similar to matched controls who had leaflet patch augmentation with glutaraldehyde-treated pericardium at 12 months follow-up, although the mechanism of failure tended to differ, with more patch retractions in the pericardium group [46]. None of these patients were operated on in the setting of acute infective endocarditis. There is only one report of CorMatrix ${ }^{\complement}$ use in infective endocarditis [47], reporting posterior mitral leaflet augmentation with CorMatrix ${ }^{\complement}$ for mitral valve $S$. viridans endocarditis in one patient, and previously repaired ventricular septal defect patch replacement with CorMatrix $@$ for $S$. aureus septal patch endocarditis and aortic root abscess. Both these patients had favorable outcomes, with local (gentamycin fleece left in situ around an aortic root graft) and systemic adapted antibiotics, although follow-up was limited to 34 days and 3 months, respectively in each patient.

Although these biodegradable materials have promising initial experimental and clinical results in noninfected valve repair, as well as theoretical advantages in an infected surgical field, there are limited reports of

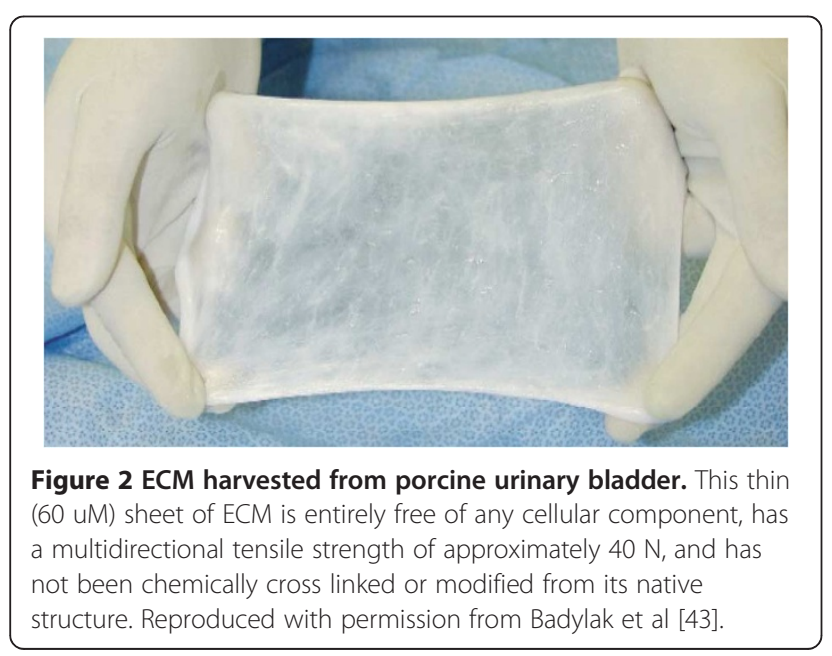

using ECM scaffolds for valve repair in infective endocarditis. In comparison, abdominal wall hernia repair using ECM scaffolds in infected settings have shown reasonable results at most, with simplified wound care and lower rate of reoperation for matrix removal compared to non-degradable materials [48], although the rate of hernia recurrence remained as high a 30\%. This last point raises the question of the adequacy of a biodegradable patch material for leaflet reconstruction during active infection, as the patch will be subjected to very high pressures while it is being remodeled. In an in vitro comparison of the biomechanical properties of patch materials after experimental infection with MRSA [49], ECM scaffolds showed a significant decrease in the ultimate tensile strength and modulus of elasticity compared to non-infected controls (see Figure 3). Taking into account both the indirect clinical observations cited above, and this in vitro experimental data, serious concerns should be raised on the use of ECM scaffolds in infective endocarditis, and thorough in vivo animal experiments are required to evaluate the biomechanical properties of these patch materials in this specific setting before clinical use.

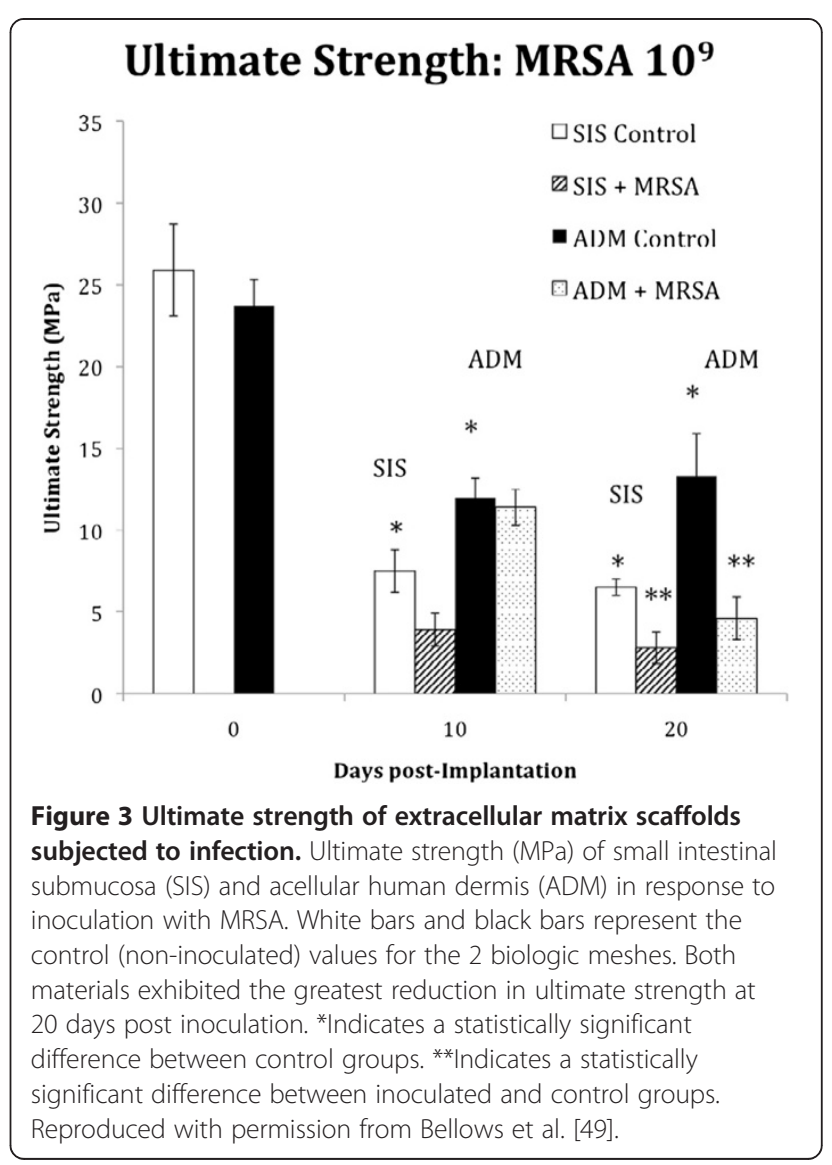




\section{Summary}

These evolving biodegradable devices, from annuloplasty rings to patch materials, offer the potential for valve repair with degradable materials replaced with autologous tissue. This is a perfect example of translational medicine, going from in vivo animal models investigating biodegradation and resistance to infection, to clinical application in the hopes that these properties could further improve the results of valve repair for infective endocarditis. This is an evolving field with promising experimental or initial clinical results, however long-term results are lacking and further data is necessary to validate this theoretically interesting approach to infective endocarditis. Furthermore, given the low rate of recurrent endocarditis using non-degradable materials, any study looking at these technologies, beyond the "proof of concept" phase we are emerging from, will need a large number of patients and rigorous follow-up to have sufficient power to see if these new biodegradable materials can do better than conventional techniques.

\section{Abbreviations}

AATS: American association of thoracic surgeons; ADM: Acellular human dermis; AVERT: Artificial Valve Endocarditis Reduction Trial; CFU: colony forming unit; ECM: extracellular matrix; ml: millilitre; MPa: megapascal (modulus of elasticity); MRSA: methycilin-resistant staphylococcus aureus; SIS: small intestinal submucosa.

\section{Competing interests}

AK was a consultant for Bioring SA, Lonay, Switzerland. None of the other authors declare any conflict of interest.

\section{Authors' contributions}

P.O.M conceived the review, performed literature searches and drafted the debate. M.C. helped conceive the review, performed literature searches and critically reviewed the manuscript. A.K. helped conceive the review, participated in its coordination and critically reviewed the manuscript. All authors read and approved the final manuscript.

\section{Received: 25 February 2014 Accepted: 24 July 2014}

Published: 3 August 2014

\section{References}

1. Hoen B, Chirouze C, Cabell CH, Selton-Suty C, Duchene F, Olaison L, Miro JM, Habib G, Abrutyn E, Eykyn S, Bernard Y, Marco F, Corey GR: Emergence of endocarditis due to group $D$ streptococci: findings derived from the merged database of the International Collaboration on Endocarditis. Eur J Clin Microbiol Infect Dis 2005, 24(1):12-16.

2. Hogevik H, Olaison L, Andersson R, Lindberg J, Alestig K: Epidemiologic aspects of infective endocarditis in an urban population. A 5-year prospective study. Medicine (Baltimore) 1995, 74(6):324-339.

3. van der Meer JT, Thompson J, Valkenburg HA, Michel MF: Epidemiology of bacterial endocarditis in The Netherlands. I. Patient characteristics. Arc Internal Med 1992, 152(9):1863-1868.

4. Thuny F, Di Salvo G, Belliard O, Avierinos JF, Pergola V, Rosenberg V, Casalta JP, Gouvernet J, Derumeaux G, larussi D, Ambrosi P, Calabro R, Riberi A, Collart F, Metras D, Lepidi H, Raoult D, Harle JR, Weiller PJ, Cohen A, Habib G: Risk of embolism and death in infective endocarditis: prognostic value of echocardiography: a prospective multicenter study. Circulation 2005, 112(1):69-75.

5. Thuny F, Grisoli D, Collart F, Habib G, Raoult D: Management of infective endocarditis: challenges and perspectives. Lancet 2012 379(9819):965-975.

6. Baddour LM, Wilson WR, Bayer AS, Fowler VG Jr, Bolger AF, Levison ME, Ferrieri P, Gerber MA, Tani LY, Gewitz MH, Tong DC, Steckelberg JM, Baltimore RS,
Shulman ST, Burns JC, Falace DA, Newburger JW, Pallasch TJ, Takahashi M, Taubert KA: Infective endocarditis: diagnosis, antimicrobial therapy, and management of complications: a statement for healthcare professionals from the Committee on Rheumatic Fever, Endocarditis, and Kawasaki Disease, Council on Cardiovascular Disease in the Young, and the Councils on Clinical Cardiology, Stroke, and Cardiovascular Surgery and Anesthesia, American Heart Association: endorsed by the Infectious Diseases Society of America. Circulation 2005, 111(23):e394-e434.

7. Habib G, Hoen B, Tornos P, Thuny F, Prendergast B, Vilacosta I, Moreillon P, de Jesus AM, Thilen U, Lekakis J, Lengyel M, Muller L, Naber CK, Nihoyannopoulos P, Moritz A, Zamorano JL: Guidelines on the prevention, diagnosis, and treatment of infective endocarditis (new version 2009): the Task Force on the Prevention, Diagnosis, and Treatment of Infective Endocarditis of the European Society of Cardiology (ESC). Endorsed by the European Society of Clinical Microbiology and Infectious Diseases (ESCMID) and the International Society of Chemotherapy (ISC) for Infection and Cancer. Eur Heart J 2009, 30(19):2369-2413.

8. Hill EE, Herijgers P, Herregods MC, Peetermans WE: Evolving trends in infective endocarditis. Clin Microbiol Infect 2006, 12(1):5-12

9. Fedoruk LM, Jamieson WR, Ling H, Macnab JS, Germann E, Karim SS, Lichtenstein SV: Predictors of recurrence and reoperation for prosthetic valve endocarditis after valve replacement surgery for native valve endocarditis. J Thorac Cardiovasc Surg 2009, 137(2):326-333.

10. Musci M, Hubler M, Pasic M, Amiri A, Stein J, Siniawski H, Weng Y, Hetzer R: Surgery for active infective mitral valve endocarditis: a 20-year, singlecenter experience. J Heart Valve Dis 2010, 19(2):206-214. discussion 215.

11. Schaff HV, Carrel TP, Jamieson WR, Jones KW, Rufilanchas JJ, Cooley DA, Hetzer R, Stumpe F, Duveau D, Moseley P, van Boven WJ, Grunkemeier GL, Kennard ED, Holubkov R: Paravalvular leak and other events in silzonecoated mechanical heart valves: a report from AVERT. Ann Thorac Surg 2002, 73(3):785-792.

12. Kuijpers AJ, Engbers GH, van Wachem PB, Krijgsveld J, Zaat SA, Dankert J, Feijen J: Controlled delivery of antibacterial proteins from biodegradable matrices. J Control Release 1998, 53(1-3):235-247.

13. Jassar AS, Bavaria JE, Szeto WY, Moeller PJ, Maniaci J, Milewski RK, Gorman $J H$ 3rd, Desai ND, Gorman RC, Pochettino A: Graft selection for aortic root replacement in complex active endocarditis: does it matter? Ann Thorac Surg 2012, 93(2):480-487.

14. Baird CW, Myers PO, Marx G, Del Nido PJ: Mitral valve operations at a high-volume pediatric heart center: Evolving techniques and improved survival with mitral valve repair versus replacement. Ann Pediatr Cardiol 2012, 5(1):13-20.

15. DiBardino DJ, ElBardissi AW, McClure RS, Razo-Vasquez OA, Kelly NE, Cohn $\mathrm{LH}$ : Four decades of experience with mitral valve repair: analysis of differential indications, technical evolution, and long-term outcome. J Thorac Cardiovasc Surg 2010, 139(1):76-83. discussion 83-74.

16. de Kerchove L, Vanoverschelde JL, Poncelet A, Glineur D, Rubay J, Zech F, Noirhomme P, El Khoury G: Reconstructive surgery in active mitral valve endocarditis: feasibility, safety and durability. Eur J Cardiothorac Surg 2007, 31(4):592-599.

17. Scher KS, Bernstein JM, Jones CW: Infectivity of vascular sutures. Am Surg 1985, 51(10):577-579.

18. Katz S, Izhar M, Mirelman D: Bacterial adherence to surgical sutures. A possible factor in suture induced infection. Ann Surg 1981, 194(1):35-41.

19. Merritt $K$, Hitchins VM, Neale AR: Tissue colonization from implantable biomaterials with low numbers of bacteria. J Biomed Mater Res 1999, 44(3):261-265.

20. Sharp W, Belden TA, King PH, Teague PC: Suture resistance to infection. Surgery 1982, 91(1):61-63.

21. Carpentier A: Cardiac valve surgery-the "French correction". J Thorac Cardiovasc Surg 1983, 86(3):323-337.

22. Hetzer $R$, Delmo Walter EM: No ring at all in mitral valve repair: indications, techniques and long-term outcome. Eur J Cardiothorac Surg 2014, 45(2):341-351.

23. Monahan TS, Phaneuf MD, Contreras MA, Andersen ND, Popescu-Vladimir A, Bide MJ, Dempsey DJ, Mitchell RN, Hamdan AD, LoGerfo FW: In vivo testing of an infection-resistant annuloplasty ring. J Surg Res 2006, 130(1):140-145.

24. Duran CM, Balasundaram SG, Bianchi S, Herdson P: The vanishing tricuspid annuloplasty. A new concept. J Thorac Cardiovasc Surg 1992, 104(3):796-801. 
25. Duran CM, Kumar N, Prabhakar G, Ge Z, Bianchi S, Gometza B: Vanishing De Vega annuloplasty for functional tricuspid regurgitation. J Thorac Cardiovasc Surg 1993, 106(4):609-613.

26. Kalangos A, Sierra J, Vala D, Cikirikcioglu M, Walpoth B, Orrit X, Pomar J, Mestres C, Albanese S, Jhurry D: Annuloplasty for valve repair with a new biodegradable ring: an experimental study. J Heart Valve Dis 2006, 15(6):783-790.

27. Cikirikcioglu M, Cherian S, Stimec B, Theologou T, Myers PO, Fasel J, Kalangos A: Morphologic and angiographic analysis to assess the safety of a biodegradable mitral annuloplasty ring. J Heart Valve Dis 2011, 20(2):199-204.

28. Kalangos A, Christenson JT, Beghetti M, Cikirikcioglu M, Kamentsidis D, Aggoun Y: Mitral valve repair for rheumatic valve disease in children: midterm results and impact of the use of a biodegradable mitral ring Ann Thorac Surg 2008, 86(1):161-168. discussion 168-169.

29. Bautista-Hernandez V, Myers PO, Loyola H, Marx GR, Bacha EA, Baird CW, del Nido PJ: Atrioventricular Valve Annular Remodeling With a Bioabsorbable Ring in Young Children. J Am Coll Cardiol 2012, 60(21):2256-2258.

30. Myers PO, Beghetti M, Kalangos A: Biodegradable mitral annuloplasty for congenital ischemic mitral regurgitation. Thorac Cardiovasc Surg 2009, 57(6):363-364

31. Mrowczynski W, Mrozinski B, Kalangos A, Walpoth BH, Pawelec-Wojtalik M, Wojtalik M: A biodegradable ring enables growth of the native tricuspid annulus. J Heart Valve Dis 2011, 20(2):205-215.

32. Panos A, Myers PO, Kalangos A: Thoracoscopic and robotic tricuspid valve annuloplasty with a biodegradable ring: an initial experience. J Heart Valve Dis 2010, 19(2):201-205.

33. Pektok E, Ekici AID, Kucukaksu S: Biodegradable Annuloplasty Ring Two Years after Implantation: First Histological Demonstration in Human Mitral Annulus. J Heart Valve Dis 2013, 22(3):445-447.

34. Kazaz H, Celkan MA, Ustunsoy H, Baspinar O: Mitral annuloplasty with biodegradable ring for infective endocarditis: a new tool for the surgeon for valve repair in childhood. Interact Cardiovasc Thorac Surg 2005, 4(4):378-380.

35. Pektok E, Sierra J, Cikirikcioglu M, Muller H, Myers PO, Kalangos A: Midterm results of valve repair with a biodegradable annuloplasty ring for acute endocarditis. Ann Thorac Surg 2010, 89(4):1180-1185.

36. Myers $\mathrm{PO}$, Kalangos $\mathrm{A}$, Pektok $\mathrm{E}$, Cikirikcioglu M: Biodegradable ring annuloplasty for valve repair in children with endocarditis. $J$ Card Surg 2012, 27(3):393. author reply 394.

37. Myers PO, Tissot C, Christenson JT, Cikirikcioglu M, Aggoun Y, Kalangos A: Aortic valve repair by cusp extension for rheumatic aortic insufficiency in children: Long-term results and impact of extension material. $J$ Thorac Cardiovasc Surg 2010, 140(4):836-844.

38. Nosal M, Poruban $R$, Valentik P, Sagat M, Nagi AS, Kantorova A: Initial experience with polytetrafluoroethylene leaflet extensions for aortic valve repair. Eur J Cardiothorac Surg 2012, 41(6):1255-1257. discussion 1258.

39. El Khoury G, Vohra HA: Polytetrafluoroethylene leaflet extensions for aortic valve repair. Eur J Cardiothorac Surg 2012, 41(6):1258-1259.

40. Farivar RS, Shernan SK, Cohn LH: Late rupture of polytetrafluoroethylene neochordae after mitral valve repair. J Thorac Cardiovasc Surg 2009, 137(2):504-506.

41. Kalfa D, Bel A, Chen-Tournoux A, Della Martina A, Rochereau P, Coz C, Bellamy V, Bensalah M, Vanneaux V, Lecourt S, Mousseaux E, Bruneval P, Larghero J, Menasche P: A polydioxanone electrospun valved patch to replace the right ventricular outflow tract in a growing lamb model. Biomaterials 2010, 31(14):4056-4063.

42. Sutherland FW, Perry TE, Yu Y, Sherwood MC, Rabkin E, Masuda Y, Garcia GA, McLellan DL, Engelmayr GC Jr, Sacks MS, Schoen FJ, Mayer JE Jr: From stem cells to viable autologous semilunar heart valve. Circulation 2005 111(21):2783-2791.

43. Badylak SF: The extracellular matrix as a scaffold for tissue reconstruction. Semin Cell Dev Biol 2002, 13(5):377-383.

44. Quarti A, Nardone S, Colaneri M, Santoro G, Pozzi M: Preliminary experience in the use of an extracellular matrix to repair congenital heart diseases. Interact Cardiovasc Thorac Surg 2011, 13(6):569-572.

45. Padalino MA, Castellani C, Dedja A, Fedrigo M, Vida VL, Thiene G, Stellin G, Angelini A: Extracellular matrix graft for vascular reconstructive surgery: evidence of autologous regeneration of the neoaorta in a murine model. Eur J Cardiothorac Surg 2012, 42(5):e128-135.
46. Myers PO, Khalpey Z, Baird CW, Nathan M, Del Nido PJ: In vivo Valvulogenesis: Initial Experience with Atrioventricular Valve Leaflet Augmentation with CorMatrix ${ }^{\circledast}$ Extracellular Matrix Scaffolds. Circulation 2012, 126:A16130.

47. Sundermann SH, Rodriguez Cetina Biefer H, Emmert MY, Falk V: Use of extracellular matrix materials in patients with endocarditis. Thor Cardiovasc Surg 2014, 62(1):76-79.

48. Cevasco M, Itani KM: Ventral hernia repair with synthetic, composite, and biologic mesh: characteristics, indications, and infection profile. Surg Infect 2012, 13(4):209-215.

49. Bellows CF, Wheatley BM, Moroz K, Rosales SC, Morici LA: The effect of bacterial infection on the biomechanical properties of biological mesh in a rat model. PLoS One 2011, 6(6):e21228.

\section{doi:10.1186/1471-2482-14-48}

Cite this article as: Myers et al:: Biodegradable materials for surgical management of infective endocarditis: new solution or a dead end street?. BMC Surgery 2014 14:48.

\section{Submit your next manuscript to BioMed Central and take full advantage of:}

- Convenient online submission

- Thorough peer review

- No space constraints or color figure charges

- Immediate publication on acceptance

- Inclusion in PubMed, CAS, Scopus and Google Scholar

- Research which is freely available for redistribution

Submit your manuscript at www.biomedcentral.com/submit
C Biomed Central 